\title{
Analisis Pengaruh Disiplin Terhadap Kinerja Karyawan Airnav Indonesia di Bandara Radin Inten II Lampung
}

\author{
Yudi Yusnandi $^{1 *}$, Ani Pujiati ${ }^{1}$, Henita Aritonang ${ }^{1}$ \\ ${ }^{1}$ Universitas Sang Bumi Ruwa Jurai \\ *Correspondence : yudiyusnandi.adv@gmail.com
}

\begin{abstract}
Abstrak.
Penelitian ini bertujuan untuk mengetahui pengaruh Disiplin dengan Kinerja Karyawan Airnav Indonesia di Bandara Radin Inten II Lampung. penelitian ini adalah penelitian kuantitatif. Pendekatan Penelitian yang dipergunakan adalah suatu pendekatan asosiatif (asosiatif kausal). Penelitian ini akan dilaksanakan kepada Karyawan Airnav Indonesia di Bandara Radin Inten II Lampung. variabel independent (X) dalam penelitian ini adalah Disiplin, sedangkan Variabel dependen (Y) dalam penelitian ini adalah Kinerja Karyawan. penelitian menggunakan teknik Sampling Jenuh yaitu berjumlah 27 orang. Pengumpulan data menggunakan kuesioner dan wawancara. Analisis data menggunakan Analisis regresi linier untuk mengetahui pengaruh variabel independen (X) terhadap variabel dependen (Y). Hasil penelitian menyatakan bahwa terdapat pengaruh antara variabel Disiplin (X) terhadap Kinerja Karyawan (Y) pada Karyawan Airnav Indonesia di Bandara Radin Inten II Lampung.
\end{abstract}

Kata kunci: Analisis Pengaruh, Airnav Indonesia, Bandara Raden Intan II Lampung, Disiplin, Kinerja Karyawan

\begin{abstract}
.
This study aims to determine the effect of Discipline on the performance of Airnav Indonesia employees at Radin Inten II Airport Lampung. this research is quantitative research. The research approach used is an associative approach (causal associative). This research will be conducted on Airnav Indonesia employees at Radin Inten II Airport Lampung. The independent variable $(X)$ in this study is discipline, while the dependent variable $(Y)$ in this study is employee performance. The research used the Saturated Sampling technique, which amounted to 27 people. Collecting data using questionnaires and interviews. Data analysis used linear regression analysis to determine the effect of the independent variable $(X)$ on the dependent variable $(Y)$. The results of the study stated that there was an influence between the Discipline variable $(X)$ on Employee Performance $(Y)$ on Airnav Indonesia Employees at Radin Inten II Airport Lampung.
\end{abstract}

Keywords: Influence Analysis, Airnav Indonesia, Raden Intan II Airport Lampung, Discipline, Employee Performance

\section{PENDAHULUAN}

Pembangunan Nasional yang saat kini sedang berjalan dan selalu beriring dengan perkembangan industri yang pesat dan mandiri semuanya itu dalam rangka industrialisasi (Nurlaili et al., 2014) yang ditandai dengan mekanisme, elektrifikasi dan modernisasi (Saputra et al., 2021), karena hal ini merupakan kebutuhan mobilitas yang tinggi, sehingga dengan fenomena ini diperlukan jenis transportasi dan salah satunya adalah transportasi udara.
Penyedia transportasi udara dan fasilitas yang dapat menyesuaikan dengan kebutuhan manusia saat ini, adalah untuk memberikan pelayanan karena banyaknya pengunaan selaku konsumen Pesawat terbang sehingga harus diperhatikan pula mengenai Bandar Udara sebagai tempat fasilitas pesawat terbang dan fasilitas penunjang lainnya.

Salah satu aspek dalam memberikan pelayanan kepada pengguna pesawat terbang adalah kedisiplinan, karena keselamatan penumpang pesawat terbang erat kainnya dengan disiplin dalam pesawat 
udara yang sedang dalam penerbangan (Makahinsade, 2016). Karena hal ini berkaitan dengan tugas Komite Nasional Keselamatan Transportasi (KNKT) adalah 1) Melaksanakan investigasi kecelakaan transportasi; 2) Memberikan rekomendasi hasil invesigasi kecelakaan transportasi kepada pihak terkait; 3) Memberikan saran dan pertimbangan kepada Presiden berdasarkan hasil investigasi kecelakaan dalam rangka mewujudkan keselamatan transportasi(Tambalean, 2020).

Sedangkan pihak pengelola Bandara harus tunduk dan patuh pada segala putusan KNKT, karena merujuk fungsi KNKT, segala hal yang berhubungan dengan kecelakaan pesawat terbang akan terkena dampak investigasi. yang berkaitan dengan segala hal yang dikeluarkan oleh KNKT, tentu saja menjadi kewajiban pihak pengelola Bandara yang harus berpedoman pada upaya-upaya keselamatan penumpang. Untuk menelusuri sebagai bentuk mensikapi upaya pengelolaan Bandara, maka aspek kedisiplinan karyawan atau pegawai merupakan hal mutlak.

Kedisiplinan dalam bekerja yang dilaksanakan oleh manusia sebagai sumber daya dengan tugas untuk menyelesaikan beban kerja yang diemban oleh para pegawai atau karyawan pada kelembagaan atau organisasi merupakan hal mutlak yang wajib dilaksanakan. Karena tanpa disiplin, suatu Lembaga akan mengalami kegagalan atau setidaknya mengalami permasalahan yang sangat berarti apalagi hal ini berkaitan dengan nyawa manusia sebagai pengguna transportasi udara. Oleh sebab itu kedisiplinan oleh pegawai atau karyawan wajib dijalankan.

Perusahaan Umum Lembaga Penyelenggara Pelayanan Navigasi Penerbangan Indonesia (LPPNPI) atau dikenal dengan Airnav Indonesia yang merupakan Badan Usaha Milik Negara (BUMN) satu-satunya penyedia jasa pelayanan navigasi penerbangan di Indonesia dan Lembaga yang mengelola seluruh ruang udara di Indonesia
(Rahmawati et al., 2019). Lembaga ini merupakan sub bagian yang melakukan kerja sama di kelembagaan Penerbangan Udara Bandara Radin Inten II yang berada di bawah langsung PT. Angkasa Pura.

Kedisiplinan kehadiran atau absensi para karyawan Perusahaan Umum Lembaga Penyelenggara Pelayanan Navigasi Penerbangan Indonesia (LPPNPI) atau dikenal dengan Airnav Indonesia yang berada di Bandara Radin Inten II Lampung telah berjalan dengan sangat baik, kedisiplinan absensi karyawan dijadikan icon atau budaya yang menjadi wajib sehingga sangat jarang sekali karyawan yang tidak masuk kerja, namun berdasarkan pengamatan, masalah utama kedisiplinan yang masih menjadi masalah pokok sehingga menjadi perhatian lembaga dan juga pimpinan yang dilakukan karyawan adalah dalam penggunaan tanda pengenal atau Id-Card Bandara, dimana pihak kelembagaan Penerbangan Udara Bandara Radin Inten II yang berada di bawah langsung PT. Angkasa Pura sering sekali menegur baik lisan ataupun tulisan sebagai bentuk peringatan dan terlebih lagi para pegawai atau karyawan masih banyak yang didalam penggunaan pakaian dinas yang masih belum sesuai dengan aturan. Bahkan masih sangat banyak hampir sebagian besar karyawan yang tidak disiplin dalam bekerja di dalam penggunaan alat telekomunikasi seperti Handphone saat bekerja.

Beranjak dari permasalahan di atas, seharusnya karyawan atau pegawai selalu menunjukkan sikap disiplin dalam bekerja. Di dalam kehidupan sehari-hari, dimanapun manusia berada, dibutuhkan peraturanperaturan dan ketentuan-ketentuan yang akan mengatur dan membatasi setiap kegiatan dan perilakunya. Namun peraturanperaturan tersebut tidak akan ada artinya bila tidak disertai dengan sanksi bagi pelanggarnya (Tri Widodo et al., 2018).

Begitu juga menurut Hasibuan (2010), disiplin adalah kesadaran dan kesediaan seseorang mentaati semua peraturan perusahaan dan norma-norma sosial yang 
berlaku (Mulyadi \& Hakim, 2021). Disiplin yang baik mencerminkan besarnya tanggung jawab seseorang terhadap tugas-tugas yang diberikan kepadanya. Hal ini mendorong gairah kerja, semangat kerja dan mendukung terwujudnya tujuan perusahaan dan pegawai (Syafrina, 2017).

Hakekat disiplin umumnya mencerminkan besarnya tanggungjawab seseorang terhadap tugas-tugas yang diberikan kepadanya (Selma \& Septayuda, 2021). Disiplin kerja diartikan jika karyawan selalu datang dan pulang tepat pada waktunya, mengerjakan semua pekerjaannya dengan baik dan tepat waktu, melaksanakan perintah atasan, dan mematuhi semua peraturan perusahaan dan norma-norma yang berlaku.

Disiplin kerja yang tinggi akan meningkatkan kinerja seorang karyawan khususnya karyawan Perum LPPNPI (Airnav Indonesia) Bandar Udara Radin Inten II bertanggung jawab melayani navigasi penerbangan untuk semua pesawat yang menuju Lampung dan sekitarnya dengan rata-rata per hari sekitar 40 pesawat.

Saat ini terdapat beberapa maskapai seperti Garuda Indonesia, Citilink, AirAsia, Batik Air, Lion Air, dan lainnya yang melayani rute menuju Lampung. Kantor Bandara Radin Inten II Lampung mempunyai tugas menyelenggarakan jasa pelayanan lalu lintas penerbangan meliputi operasi lalu lintas penerbangan, pengoperasian, pemeliharaan, dan perbaikan fasilitas Teknik navigasi penerbangan, serta pengelolaan dan pengendalian kegiatan keuangan dan administrasi.

Saat ini juga (Perum) Lembaga Penyelenggara Pelayanan Navigasi Penerbangan Indonesia (LPPNPI) Lampung yang berada di Bandara Radin Inten II mempunyai karyawan sebanyak 27 orang terdiri dari unit Finance \& Administration, ATS Operation, ATS Engineering dan Security/OB.

Dengan adanya kedisiplinan dalam bekerja dipastikan capaian kinerja karyawan atau pegawai selaku sumber daya manusia akan tercapai sebab kedua elemn ini ada hubungannya, Menurut Moeheriono (2010) menjelaskan bahwa kinerja adalah hasil kerja yang dapat dicapai oleh seseorang atau kelompok orang dalam suatu organisasi, sesuai dengan tanggungjawab masingmasing, dalam rangka mencapai tujuan organisasi yang bersangkutan secara legal, tidak melanggar hukum dan sesuai dengan moral atau etika (Apriadi et al., 2020).

Bila beranjak dari pengertian kinerja sebagaimana di atas, maka kinerja karyawan pada Pelayanan Navigasi Penerbangan Indonesia (LPPNPI) Bandara Radin Inten II Lampung harus terwujud dengan bentuk beban kerja sesuai Undang-Undang No. 1 tahun 2009 tentang Penerbangan adalah melakukan pelayanan lalu lintas penerbangan (Air Traffic Services/ATS) yang terdiri atas 1) Pelayanan pemanduan Ialu lintas penerbangan (Air Traffic Control Service); 2) Pelayanan informasi penerbangan (Flight Information Service); dan 3) Pelayanan kesiagaan (Alerting Service).

Selama pengerjaan beban tugas sebagai bentuk Pelayanan Navigasi Penerbangan Indonesia (LPPNPI) Bandara Radin Inten II Lampung sesuai Undang-Undang No. 1 tahun 2009 tentang Penerbangan salah satu faktor yang menjadi penyebab kurang optimalnya pemberian pelayanan navigasi penerbangan kepada pengguna jasa masih lemahnya kinerja oleh karena lemahnya sistem tata kelola perusahaan. Hal itu terjadi karena Perusahaan masih dalam proses pembelajaran menuju sistem tata kelola yang efektif dan efisien.

Dari hal tersebut di atas, berdasarkan pengamatan karyawan hendaknya mengetahui tujuan dan kemampuan dalam bekerja, mengikuti arahan dari keteladanan pimpinan, menerima balas Jasa dan keadilan, mematuhi waskat (pengawasan melekat), menerima Sanksi hukuman, dan bertindak dengan ketegasan dalam bekerja dan menciptakan hubungan kemanusiaan sesama rekan kerja. 
Kinerja ekonomi AirNav dalam tata Kelola perusahaan tercatat cukup baik di tahun 2019 hingga tahun 2020 (berlaku untuk Airnav seluruh Indonesia) meski menghadapi berbagai ketidakpastian di industri penerbangan terutama masa pandemic Covid-19. Tercatat pertumbuhan laba bersih tahun 2019 sebesar Rp500,18 miliar, meningkat 23,74\% dari tahun 2018 yang dibukukan sebesar Rp381,45 miliar. Pendapatan usaha AirNav di tahun 2019 yaitu sebesar Rp3,45 triliun, meningkat 4,93\% dari tahun 2018 sebesar Rp3,28 triliun.

Seiring dengan meningkatnya pendapatan, AirNav menyalurkan dana pengembangan masyarakat pada tahun 2019 sebesar Rp7,2 miliar melalui Program Kemitraan dan Bina Lingkungan (PKBL). Sebagai Badan Usaha Milik Negara, AirNav juga turut berkontribusi melalui penyetoran pajak dan Penerimaan Negara Bukan Pajak (PNBP) dengan nilai total mencapai Rp311,29 miliar. Kinerja ekonomi AirNav Indonesia yang baik tidak terlepas dukungan sumber daya manusia yang handal dan profesional. AirNav terus memperkuat diri dengan merekrut dan mengembangkan tenaga kerja dari seluruh Nusantara. Sepanjang tahun 2019, sebanyak 2.748 karyawan telah mengikuti 160 kegiatan pendidikan dan pelatihan yang bersifat mandatory maupun non-mandatory. Kemudian, melalui AirNav Scholarship Program (ASP), AirNav Indonesia mengembangkan potensi tenaga kerja local (Laporan Kinerja Direktur Airnav, 2019).

Berdasarkan pengamatan terhadap karyawan Airnav Indonesia di Bandara Radin Inten II Lampung, kinerja karyawan belum sepenuhnya memiliki kemampuan untuk bekerja secara efektif, masih ada yang kurang paham standar pekerjaan yang telah ditetapkan, dan juga ada yang kurang mengerti memenuhi deskripsi pekerjaan yang telah ditentukan oleh organisasi. Dimaklumi memang perusahaan ini masih menerapkan sistem yang baru yang masih perlu dikuasai dengan pemahaman, sehingga dari hal ini kinerja karyawan secara perorangan belum memenuhi faktor motivasi, yaitu hasrat untuk melakukan pekerjaan, dan juga kemampuan, yaitu kemampuan seseorang untuk melakukan pekerjaan tersebut, serta ada beberapa karyawan yang masih perlu melakukan adaptasi pekerjaan terutama memahami lingkungan pekerjaan, seperti pemahaman tentang peralatan, bahan, dan informasi yang dibutuhkan untuk melakukan pekerjaan.

Dari uraian di atas, maka penelitian ini bertujuan untuk mengetahui pengaruh Disiplin dengan Kinerja Karyawan Airnav Indonesia di Bandara Radin Inten II Lampung.

\section{METODE PENELITIAN}

Jenis penelitian yang digunakan dalam penelitian ini adalah penelitian kuantitatif. Pendekatan Penelitian yang dipergunakan adalah suatu pendekatan asosiatif (asosiatif kausal). Penelitian ini akan dilaksanakan kepada Karyawan Airnav Indonesia di Bandara Radin Inten II Lampung, Jalan Alamsyah Ratu Prawira Negara KM 28, Branti Natar Lampung Selatan, Lampung, Kel. Beranti/Branti Raya, Kec. Natar, Kab. Lampung Selatan, Lampung, yang berlangsung dari Bulan Mei hingga Juni 2021.

variabel independent $(\mathrm{X})$ dalam penelitian ini adalah Disiplin, sedangkan Variabel dependen ( $\mathrm{Y}$ ) dalam penelitian ini adalah Kinerja Karyawan. penelitian menggunakan teknik Sampling Jenuh. Oleh karena Karyawan Bandara Radin Inten II Lampung bidang Airnav berjumlah 27 orang, maka penelitian ini menjadikannya sebagai responden secara keseluruhan. Teknik pengumpulan data menggunakan kuesioner dan wawancara. Analisis data menggunakan Analisis regresi linier untuk mengetahui pengaruh variabel independen (X) terhadap variabel dependen $(\mathrm{Y})$.

\section{HASIL DAN PEMBAHASAN}


Setelah data dikumpulkan, dilanjutkan ke tahap analisis data. Penghitungan statistik regresi linier sederhana pengaruh Disiplin terhadap Kinerja Pegawai perlu membuat sebuah rumusan hipotesis penelitian sebagai berikut:

Ho: Tidak ada pengaruh yang signifikan Disiplin terhadap Kinerja Pegawai.
Ha: Terdapat pengaruh yang signifikan Disiplin terhadap Kinerja Pegawai.

Apabila nilai thitung $>t_{\text {tabel, }}$ maka Ho ditolak dan Ha diterima. Sebaliknya, apabila nilai $t_{\text {hitung }}<\mathrm{t}_{\text {tabel, }}$ maka Ho diterima dan Ha ditolak. Hasil dari perhitungan statistik regresi linier sederhana menggunakan hasil perhitungan melalui program SPSS For Windows 21.0 adalah sebagai berikut:

Tabel 1. Uji Hipotesis Pengaruh Disiplin (X) terhadap Kinerja (Y)

\section{Coefficients $^{\mathrm{a}}$}

\begin{tabular}{|c|c|c|c|c|c|}
\hline \multirow[t]{2}{*}{ Model } & \multicolumn{2}{|c|}{$\begin{array}{l}\text { Unstandardized } \\
\text { Coefficients }\end{array}$} & \multirow{2}{*}{$\begin{array}{c}\begin{array}{c}\text { Standardized } \\
\text { Coefficients }\end{array} \\
\text { Beta }\end{array}$} & \multirow[t]{2}{*}{$\mathbf{t}$} & \multirow[t]{2}{*}{ Sig. } \\
\hline & B & Std. Error & & & \\
\hline 1 (Constant) & 1.545 & 2.841 & & .544 & .591 \\
\hline $\mathrm{X}$ & .957 & .079 & .924 & 12.090 & .000 \\
\hline
\end{tabular}

Berdasarkan hasil uji t didapat nilai thitung $=12,090$. Apabila dibandingkan dengan ttabel pada taraf signifikan 0,05 yaitu 2,76, maka thitung $=12,090>t_{\text {tabel }} 2,76$ sehingga dapat disimpulkan bahwa hipotesa yang menyatakan terdapat pengaruh antara variabel Disiplin (X) terhadap Kinerja
Karyawan (Y) pada Karyawan Airnav Indonesia di Bandara Radin Inten II Lampung. Jadi variabel disiplin (X) berpengaruh terhadap variabel Kinerja (Y).

Berdasarkan hasil penilitian, diperoleh koefisien determinasi Disiplin terhadap Kinerja adalah sebagai berikut:

Tabel 2. Koefisien Determinasi DisiplinTerhadap Kinerja Model Summary ${ }^{b}$

\begin{tabular}{|c|c|c|c|c|c|c|c|c|c|}
\hline \multirow[b]{2}{*}{ Model } & \multirow[b]{2}{*}{$\mathbf{R}$} & \multirow[b]{2}{*}{$\begin{array}{c}\text { R } \\
\text { Square }\end{array}$} & \multirow[b]{2}{*}{$\begin{array}{l}\text { Adjusted } \\
\text { R Square }\end{array}$} & \multirow{2}{*}{$\begin{array}{l}\text { Std. Error } \\
\text { of the } \\
\text { Estimate }\end{array}$} & \multicolumn{5}{|c|}{ Change Statistics } \\
\hline & & & & & $\begin{array}{l}\text { R Square } \\
\text { Change }\end{array}$ & $\begin{array}{c}\text { F } \\
\text { Change }\end{array}$ & df1 & df2 & $\begin{array}{c}\text { Sig. F } \\
\text { Change }\end{array}$ \\
\hline 1 & $.924^{\mathrm{a}}$ & .854 & .848 & 1.82211 & .854 & 146.169 & 1 & 25 & .000 \\
\hline
\end{tabular}

Koefisien Determinasi $\mathrm{R}^{2}=0,9242=$ $0,854=0,854 \times 100=85,4 \%$ Dapat disimpulkan bahwa variabel Disiplin menjelaskan variasi perubahan terhadap variabel KinerjaKaryawan Airnav Indonesia di Bandara Radin Inten II Lampung sebesar $85,4 \%$, sedangkan sisanya sebesar $14,6 \%$ dijelaskan oleh faktor lain yang tidak dikaji dalam penelitian ini, oleh sebab dalam dinamika kehidupan manusia, pegawai Karyawan Airnav Indonesia di Bandara Radin Inten II Lampung pada saat penelitian Disiplindan Kinerja saling mempengaruhi hal in dibuktikan dengan nilai koefisien determinasi sebesar $85,4 \%$ dan sisanya sebesar 14,6\% dipengaruhi oleh faktor lain, dalam hal ini dapat saja variabel semangat kerja, motivasi kerja, lingkungan kerja, efektifitas, kepemimpinan dan lainnya adalah variabel lain yang sebenarnya mempengaruhi pada saat penelitian ini berlangsung, hanya saja peneliti hanya melihat dan mengekspresi variable Disiplin dan Kinerja saja.

Persamaan regresi antara variabel Disiplin terhadap Kinerjakaryawan adalah $\mathrm{Y}=1,545+0,957 \mathrm{X}$, yang artinya setiap kenaikan satu point daripada variabel Disiplin akan diikuti oleh naiknya variabel Kinerjapada Karyawan Airnav Indonesia di 
Bandara Radin Inten II Lampung sebesar 0,957 point.

\section{KESIMPULAN}

Dari pembahasan yang telah diuraikan, maka dapat ditarik kesimpulan bahwa hasil pengujian hipotesis Disiplin menunjukkan nilai thitung $=12,090$. bila dibandingkan dengan ttabel pada taraf signifikan 0,05 yaitu 2,76, maka $t_{\text {hitung }}=12,090>t_{\text {tabel }} 2,76$ sehingga disimpulkan hipotesa yang menyatakan terdapat pengaruh antara variabel Disiplin(X) terhadap Kinerja (Y) pada Karyawan Airnav Indonesia di Bandara Radin Inten II Lampung. Jadi variabel $\operatorname{Disiplin}(\mathrm{X})$ berpengaruh terhadap variabel Kinerja (Y) diterima.

Koefisien Determinasi $\mathrm{R}^{2}=0,9242=$ $0,854=0,854 \times 100=85,4 . \%$. Dapat disimpulkan bahwa variabel Disiplin menjelaskan variasi perubahan terhadap variabel Kinerja pada Karyawan Airnav Indonesia di Bandara Radin Inten II Lampung sebesar $85,4 \%$, sedangkan sisanya sebesar $14,6 \%$ dijelaskan oleh faktor lain yang tidak dikaji dalam penelitian ini, oleh sebab dalam dinamika kehidupan manusia, pegawai Karyawan Airnav Indonesia di Bandara Radin Inten II Lampung pada saat penelitian Disiplindan Kinerja saling mempengaruhi hal ini dibuktikan dengan nilai koefisien determinasi sebesar 85,4\% dan sisanya sebesar $14,6 \%$ dipengaruhi oleh faktor lain, dalam hal ini variabel lingkungan kerja, efektifitas, kepemimpinan dan lainnya adalah variabel lain yang sebenarnya mempengaruhi pada saat penelitian ini berlangsung, hanya saja peneliti hanya melihat dan mengekspresi variable Disiplindan Kinerja saja.

Selanjutnya persamaan regresi antara variabel Disiplinterhadap Kinerja adalah $\mathrm{Y}=$ $1,545+0,957 \mathrm{X}$, yang artinya setiap kenaikan satu point daripada variabel Disiplinakan diikuti oleh naiknya variabel Kinerja pada Karyawan Airnav Indonesia di Bandara Radin Inten II Lampung sebesar 0,957 point.

\section{DAFTAR PUSTAKA}

Apriadi, D., Susena, K. C., \& Irwanto, T. (2020). Analisis Pegawai Pada Kantor Kesbangpol Kabupaten Kaur. BIMA Journal (Business, Management, \& Accounting Journal), 1(2), 97-104. https://doi.org/10.37638/bima.1.2.97104

Makahinsade, V. (2016). Sanksi Pidana Pelaku Kejahatan dalam pesawat Udara Menurut Undang-Undang Nomor 1 Tahun 2009 Tentang Penerbangan. Lex Administratum, 4(2), 149-157. http://www.bssaonline.org/content/95 /6/2373\%5Cnhttp://www.bssaonline.o rg/content/95/6/2373.short\%0Ahttp:// www.bssaonline.org/cgi/doi/10.1785/ 0120110286\%0Ahttp://gji.oxfordjour nals.org/cgi/doi/10.1093/gji/ggv142\% 0Ahttp://link.springer.com/10.1007/s 00024-013-0646

Mulyadi, A., \& Hakim, L. (2021). Pengaruh Konformitas Terhadap Kedisiplinan Anggota Resimen Mahasiswa di Sumbawa. JURNAL PSIMAWA, 4(1), 41-58.

Nurlaili, N., Witomo, C. M., \& Zamroni, A. (2014). Potensi Dan Permasalahan Sosial Ekonomi Masyarakat Perikanan Kabupaten Lombok Timur Dalam Mendukung Industrialisasi. Buletin Ilmiah Marina Sosial Ekonomi Kelautan Dan Perikanan, 9(2), 41-48. https://doi.org/10.15578/marina.v9i2. 429

Rahmawati, R., Aswia, P. R., \& Surtiningtyas, S. R. (2019). Studi Penerapan RNAV-1 Dalam Peningkatan Kapasitas Ruang Udara APP/TMA Palembang. Jurnal Ilmiah Aviasi Langit Biru, 12(3), 155-162.

Saputra, S., Makomulamin, M., \& Hayana, H. (2021). Hubungan Antara Faktor Pekerja Dan Pekerjaan Dengan Work Accident Di Bagian Station Press Pks 
Pt. Hasil Karya Bumi Sejati Kabupaten Rokan Hilir Tahun 2020. Media Kesmas (Public Health Media), 1(3), 825-837.

Selma, \& Septayuda, I. (2021). ANALISIS DISIPLIN KERJA PEGAWAI DALAM MENINGKATKAN KUALITAS LAYANAN DI BALAI PKB DINAS PERHUBUNGAN OKI. Seminar Hasil Penelitian Vokasi (SEMHAVOK), 3(1), 1-7.

Syafrina, N. (2017). Pengaruh Disiplin Kerja Terhadap Kinerja Karyawan Pada PT. Suka Fajar Pekan Baru. Eko Dan Bisnis, 4(8), 1-12. https://ekobis.stieriauakbar.ac.id/index.php/Ekobis/article/v iew/5

Tambalean, J. (2020). Investigasi kecelakaan Pesawat Udara Sipil Menurut Undang-Undang Nomor 1 Tahun 2009 Tentang Penerbangan. Lex Et Societatis, 8(1), 117-125. http://www.akrabjuara.com/index.php /akrabjuara/article/view/919

Tri Widodo, T., Alamsyah, N., \& Utomo, C. B. (2018). Analisis Pengaruh Gaya Kepemimpinan, Disiplin Kerja Dan Pelatihan Kerja Terhadap Kinerja Karyawan Di PT Telkom Indonesia Cabang Batam. Jurnal Industri Kreatif (Jik), 2(1), 97-104. https://doi.org/10.36352/jik.v2i1.77 